Denkbild

\title{
Time Traveler: On Critical Theory in the Philippines Part II (A Philosophical Fiction)
}

\section{F. P. A. Demeterio}

$\mathrm{D}$ r. Max Felix Silva, dean of the Graduate School of Philosophy and the senior students' professor of critical theory, was still engrossed in discursively analyzing the transcripts of the peace negotiations between the government panel and the representatives of the Moro Islamic Liberation Front. He was trying to show his students the practical use of the German sociologist and philosopher Jürgen Habermas' doctrine that in order to attain optimum results in a dialogue the participants should only use statements and actuations that are truthful, sincere and appropriate all of the time. "Okay, class. You can be truthful but insincere, or you can be truthful and sincere but in an inappropriate way, or you can be appropriate and sincere but not truthful. The point of Habermas is simple: failing in just one of these triple criteria can already jeopardize the outcome of any consensus building. Ako ba ay nasusundan n'yo pa?"

Half of Charles' mind was focused on this rather jovial professor, but a quarter of it was already restlessly going over the things he still had to do before rushing to his night job at Makati City, while the remaining quarter was absorbed in an existential meditative appreciation of the beauty and sexual attractiveness of Anne, his pretty classmate who was seated in front of him. Ang ganda talaga nitong Anne na 'to! Alam kong totoong pag-ibig 'tong nararamdaman ko; at kung sasabibin ko man sa kanya 'to, palagay ko ay sincere naman siguro ako; problema ko na lang kung paano ko sasabibin 'yon in an appropriate manner! Habermas was one of the younger thinkers of the Frankfurt School, and Charles had been too familiar with his thoughts due to Sir Peter's long standing fascination and intellectual affair with this Jewish-German group. Hence, he could easily follow Dr. Silva's lecture even if his eyes were totally focused on Anne's dangerous curves.

Charles Mendoza first came to that microcosm that thrived on Recto Street some four years ago, all the way from his historic town of Malolos, in the province of Bulacan. Burdened with an obligation to add one more link to the chain of Mendoza lawyers that is already five generations old, he was beaconed to this area by the prestigious reputation of one of its law schools, the one that is situated near the ominous shadows of Malacañang. His original intention was to take up political science as a preparation for law, but it turned 
out that in that school of his choice this particular degree program had been inexistent for over a quarter of a century after it was phased out during the early years of the Martial Law. Without much choice, he reluctantly experimented with the philosophy program. Anak ng tipaklong, philosophy! Pangpilosopo lang 'to. T'yak dakdakan at dakdakan lang ang mapapala ko dito. Sabagay, dakdakan at dakdakan din naman ang papatungohan ko sa abogasya. However, his initial impression of this course as something to do with very deep analysis of things that maybe appealing to the ancient Greek, Chinese, Hindu and Medieval sages, but are hardly significant to contemporary living, was proven wrong. In that college, philosophy was studied side by side with its use in analyzing the problems of Philippine society, culture and ideology, as well as in the more individualistic concerns of finding meaning in one's existence. His newly found interest was fueled further when he came to know Fred and his crowd: Juliana, his exquisite girlfriend; Sir Peter, his literature professor; Ms. Faith, his industrial chemistry professor; and Mang Nato, a street sage.

After thirty more minutes of being distracted by the otherworldly vision that was Anne, who probably was not even aware that somebody was watching her from the back of her seat, Charles heard the baritone voice of Dr. Silva dismissing their class. "Ladies and gentlemen, I will focus my discussion on the historical background of the rise of the Moro Islamic Liberation Front the next time we meet. Good day!" He wondered whether his professor had imbibed that faint trace of Maranao accent from interviewing too many Filipino Muslims for his dissertation, or from haggling over the prices of too many DVDs with the Maranao traders at the constricted alleys of the Quiapo district. In any manner, this affable professor was their resident expert on Islamic studies as well as in contemporary German philosophy, and the seniors who are aiming to bag the best thesis award flock under his thorough and meticulous mentorship.

In his daydream, Charles bade goodbye to Anne with a light kiss on her flushed cheeks and she hugged him in return with a soft whisper to take good care of himself always. Bye bye, beauty! It had been a joy just to be seated next to you. I will see you again tomorrow. I bonestly wonder though if you are even aware that I exist in this world. He rushed to the stairway and proceeded to the main exit. Just outside the gates of his college, Mang Nato, their ambulant vendor friend, alerted him: "Hoy, Charlie! Sir Peter is at the Don Chino Roces Bridge with some scores of young professionals and students."

"Talaga? Oo nga pala. Now I remember him mentioning that plan to me the other day. Let us go, then, and see."

"Go ahead, young man. I will join you there. Let me just attend to my customers for a few minutes. Alam mo naman itong mga ka-eskwela mo, masyadong matampohin."

The bridge was famous not because of its being an architectural marvel, for on the contrary it was just a drab piece of concrete with nondescript railings on either side; and nor because of some bucolic scenery of a crystalline stream that gurgles along lush green banks, for on the contrary it 
squatted over an outdated colonial open sewer that channelled urban slime to the Pasig River. What made that bridge a symbolic icon to the minds of the Filipinos was the fact that it had been consecrated over and over again with the blood of our brave fellow countrymen who offered their bodies to the fascist and intolerant nature of Philippine democracy. It was their blood that made the bridge a hallowed space where activists and anti-administration critics could condemn the government's wrong doings and shortcomings and demand for their appropriate correction. Thus, there would be no amount of government propaganda and presidential or executive orders that could de-consecrate and de-construct the sacredness and symbolic status of the Mendiola Bridge. But instead of listening to the crisp and clear voices of the people, the government merely installed as its monitoring device a clearly dumb bunch of anti-riot police, heavily padded, conceitedly brandishing their truncheons, and devoid of any inkling that in the first place political rallies are necessary for the growth and further development of any democratic society.

It was on January 22, 1987, when a throng of about ten-thousand peasants marched into this bridge to demand real land reform from the Aquino government. During her campaign for presidency, Corazon Aquino pledged that an affective solution to the country's worsening agrarian problem will be at the top of her agenda. But after the EDSA revolution installed her as president, she conveniently forgot all about her promise. When the farmers converged at the Don Chino Roces Bridge, her revolutionary government that had the reputation of toppling the abusive and graft ridden Marcos dictatorship through a peaceful mass action ironically responded with appalling violence when its anti-riot policemen open fired at the helpless farmers, fatally downing nineteen and injuring hundreds of them. This carnage came to be known as the Mendiola Massacre, and it marred Aquino's chance of grabbing the Nobel Prize for peace.

The old vendor easily found Charles before the student even reached the southern approach of the bridge. "Alam mo, Mang Nato? This historic tragedy has a special place in Sir Peter's heart for he had lost a very special friend on the same clamor for a more equitable redistribution of agricultural lands and at the hands of the same supposedly more humane and egalitarian regime. Kaya siguro nandito ang grupo n'ya ngayon."

"Alam ko rin 'yan, Charlie. Nabanggit na sa akin 'yan ni Peter. Pati na 'yong tungkol sa kaibigan n'ya'ng si Francis. Huwag kang mag-alala, bijo, tikom ang bibig ko d'yan. Sa edad ko na 'to, iba't ibang tao na nakasalamuha ko. Pero ang mahalaga parati ay kung ano ang nilalaman ng kalooban mo. Hangang-hanga pa rin ako kay Peter." Charles was relieved to learn that he was not the only one keeping Sir Peter's deepest secrets.

That evening, Peter Mirano's group was staging a vigil to commemorate the eighteenth year of that political bloodbath. The peasant groups from northern, southern and central parts of Luzon were not expected to converge there until the following day. At the northern approach of the bridge, just in front of a hastily arranged barricade of steel and barbed wires, about fifty young men and women, each one holding a lighted candle, were 
seated on paper mats in a big circular formation. At their center stood a pedestal bearing nineteen enlarged photocopies of the passport pictures of the slain farmers that were symbolically smeared with red poster paint. Freshly cut flowers were strewn at the foot of their improvised martyrs' shrine.

The absence of placards and red banners, of fiery speeches, of heckling and fist-raising, and of the anti-riot police's rhythmic clanging of their truncheons against their battered shields, all suggested that the group was up to a different sort of political gathering. The silence, the eerie glow of the candles, and the enigmatic installation at their center surprisingly attracted the attention of some students, who otherwise would just ignore the ongoing political exercise as one more among the hundreds that they would probably witness throughout their studies in that elitist end of the university belt.

Charles and Mang Nato joined one of the clusters of curious students at the sidelines. The secretary general of the organization opened the ceremonies with a speech. "Mga kapatid, on this eve of the eighteenth anniversary of the massacre, the souls of the slain farmers, together with the souls of all the other martyrs of our country's political intolerance, are most probably asking themselves what is happening with the spirit of activism and vigilance of our youth. Bakit tila natutulog na nang mabimbing ang kabataang Pilipino? Bakit tila wala na silang paki-alam sa mga pangyayari sa ating bayang mahal? Hence, we decided to observe this year's anniversary with a simple vigil that will explore the question why is it that the young Filipinos are no longer bothered by the glaring incompetence, injustices and abuses of our government. Sana may mapulot tayong mga mahabalagang aral sa gabing ito. Mabubay ang demokrasya sa Pilipinas! Mabubay ang kabataang Pilipino! Mabubay tayong labat?'

A political science professor from a state-owned technological university, probably the eldest person in the group, offered a sardonic hypothesis. "The nation is probably running out of young people who are genetically predisposed to be politically courageous, as their kind might have been wiped out by the protracted struggle against the Spaniards, the Americans, the Japanese, and the long and cruel Marcos dictatorship. It is sad to speculate that it is those who shirked away from the battlefields and the streets who got the greater chances of raising kids who are unfortunately genetically wired to be submissive and subservient. The hundreds of years of colonization, and the decades of totalitarianism had taken its toll on the Filipino gene pool, transforming the once proud and valiant people into a nation of cowards." He was interrupted by chuckles and some rather rude remarks. But he was able to subdue these reactions with his concluding lines: “Alam ko'ng nakakalungkot ang sinabi ko. Pero dapat ang natitirang dugong bayani na dumadaloy sa mga ugat natin ay magagamit natin para bimukin ang ibang kabataan upang tayong lahat ay tumayo at maninindigan alang-alang sa ating mga karapatan!"

A lady fictionist and literary critic held the megaphone to lay down another explanation that emphasized the Filipinos' collective frustration with the idea of political activism. "Because nothing seemed to have happened with the lives that we have invested during the struggles against Spain and America of the past, and against the Marcos and the Estrada administrations of the 
more recent times, we now look at political oppression as a monstrous hydra of the Greek mythology, for once we succeed in cutting off a head a new and even more monstrous one would immediately sprout. This leads to that common thinking that perhaps it is wiser to just leave the leviathan alone." The group reflected on the lady's very fitting classic and literary metaphor, but after a few minutes of silence their faces turned towards Peter implying that they were expecting him to contribute something to the discussion.

The dedicated professor of literature and fire-breathing street activist attempted to connect the phenomenon of dying activism with the legendary Filipino trait of extreme tolerance, which seemed to have been reinforced by the present educational system. "Our high school and college education have the tendency to conveniently gloss over the serious political, historical and philosophical studies. Instead of training our young students to form a receptive, critical, and vigilant outlook, these educational systems are inclined to narrow down their fields of vision to their modular studies with a promised incentive that doing so would give them better chances of employment at the big corporations. It is not a wonder why there seems to be that widespread idea among our students that they should not exchange the good life that they can have in the future with the risky and dangerous political activism of the present."

The three hypothetical accounts of the decline of the spirit of activism and vigilance of the Filipino youth, although not thoroughly explored and studied yet, appeared to be very convincing, and the group of young professionals and students tended to agree with them. Even the political science professor's derisive genetic reason, after its consequent laughter had abated, delivered a rather sharp sting of truth. Charles shared to the old man his observation: "Palagay ko, Mang Nato, those three hypotheses are not actually competing and contradictory with each other, for it is very possible that the genetically weakened Filipino youth are frustrated with the idea of political activism and are further distracted from engaging in it by an educational system that conditions their mind to narrowly focus on their academic modules. Hindi po ba?"

"Tama ka, Charlie boy! That same idea crossed my mind also. I am sure the phenomenon that is as complex as the youth's dying activism would require several complimentary explanations."

A gay student leader from the prime state university received the megaphone from the secretary general and intoned an old babailan's prayer imploring the great spirits of the skies and mountains to bless and protect their peace-loving community. "Dakilang diwata sa kalangitan, ibuhos mo sa aming mga mata at isip ang liwanag ng iyong kaharian upang maging mapagmatyag kaming iyong mga timawa sa mga panganib at karahasang dala ng mga kalaban ng bayan. Dakilang diwata sa kabundokan, kupkopin mo kami at ilayo sa mga taong may maiitim na kalooban. .." Then the group stood up and a lady wearing a brown leather jacket strummed her guitar and led the singing of a famous kundiman, a poignantly melodic love song that in the past accompanied the brave Filipino revolutionaries as they moved towards their battlefields. That was the same music that awakened the 


\section{TIME TRAVELER}

heroic spirits of the nation during the first EDSA revolution, and even though this group, like many other Filipinos, was already disenchanted with its promises for social renewal, that kundiman continued to evoke powerful emotions and tears. Charles was not in the mood for weeping that night. Thus, while Mang Nato was belting out the lyrics straight from his heart, he whispered to him: "It's getting late. I have to go ahead, I need to rush back to my dormitory to get ready for my night job. Magandang gabi sa 'yo, kaibigan ko."

"Mag-ingat ka palagi, Charlie! Kakausapin ko lang muna si Peter mayamaya."

Charles had just lost forty-five precious minutes for the short nap that he had to take to fend off the spell of drowsiness during the long working hours ahead. But he was pleased with the new insights he had just gathered from the bridge that he was sure he will treasure for a very long time. At his dormitory, he hurriedly took a shower, reminding himself that Fred and Juliana might already be waiting for him at the diner in front of her dormitory. He put on a clean white shirt, and faded denim pants, hopped into his weathered tennis shoes, picked up his brown denim jacket and a couple of philosophy books, and started to walk towards the Saint Agatha Ladies' Home.

Their restaurant was a very small place, consisting of just about five tables, a food counter carrying all of what it has to offer in eight aluminum pots, a soft drinks ice cooler, and the portly lady server who was simultaneously the cook, the cashier, the manager and the owner. After more than a decade in business, the diner had already earned a name associated with generous servings and delicious array of home-style choices, making it always packed with students and other blue-collar workers, especially during meal times. When Charles arrived, his two friends had already commandeered a corner table and were sweetly talking about stuff that lovers usually talk about when waiting for someone or something. "Pssst. Over here, Charlie!"

Their arrangement of eating together whenever it was possible was both economically and relationally advantageous. Fred would usually pick a meat dish, Juliana a vegetable dish, and Charles another meat dish or fish. By sharing their choices together, and with the diner's fragrant and fluffy rice and free cups of soup, they would have not only a university belt banquet but also an opportunity to bond further as very special friends. Before proceeding to their table, Charles picked up three bottles of American soda, to take advantage of the fact that Sir Peter, who frowned on the idea of patronizing transnational goods, was not around. They perfectly understood the ideological point of their political guru, but the two boys simply found it very difficult to detach themselves from the fizz and the thirst-quenching pleasure from an ice cold glass of this drink.

Juliana greeted Charles with an insinuation. "Hi Charlie, would you be interested in taking out my new dormitory friend, Tina. Bagong lipat lang s'ya. Ay, pagnakita mo s'ya. . . sobrang ganda n'ya?'

Before he could answer Fred already interjected: "Save yourself the trouble of setting him a date, lady, I am sure Charlie is so faithful to Anne. T'yak di mo alam that mister lover boy here is in an extremely secret 
relationship!" Charles knew Fred's wicked punch line and continued the yarn by murmuring: "Ob yeah, it is indeed a top secret thing, even Anne herself does not know about it yet!"

After a hearty laugh they started to work on the hefty servings of beef stewed in tomato sauce, stir fried mixed vegetables, grilled fresh water fish, steamed rice, the house's soup of the day, and the glasses of the otherwise forbidden American soda. Charles casually recounted his late afternoon with Mang Nato and Sir Peter at the historic Mendiola bridge. "Okay ang ginawa nilang memorial rites doon. Napakadrama talaga ito'ng si Sir Peter. Kaya tuloy napaiyak pati si Mang Nato!"

After their dinner, Fred and Juliana stood up to go back to her dormitory's reading area to study until midnight. "Hey, Julie! Do you have a picture of that Tina friend of yours?"

"I thought you were not interested, lover boy? But I'll see if I can get a stolen shot of her with my cell phone." Charles started to walk alone again towards Quiapo church where a bus will take him to the heart of Makati's business center.

That late night, there were very few passengers inside the huge vehicle, making its interior colder and prompting Charles put on his brown jacket and snuggle himself in a corner seat. Ang swerte mo talaga, Fred! You are so lucky for finding such a stunning lady like Julie. But it is so depressing to think that she is actually leaving the country as soon as she finishes her nursing studies. Anne, my secret crush, may not be as spectacular as Julie, but if I can have her as a girlfriend, oh, that would make me more at ease going out on a foursome date with Freddie and Julie. But I think. Anne is really so out of my league. I even doubt if I can actually have a good chance befriending her. The likes of her seems to be genetically wired to pair off with the captain of the varsity basketball team, or with the president of the central student council, or with a son of some prominent politician. What if, by a freak twist of luck, she would agree to have dinner with me? That would be a situation! Surely I just cannot take her to our favorite diner, not even to our preferred tea house at Ongpin Street. The fancy restaurants at the Malate area or at Morato Street would be the appropriate places for her. Oh shit! Those rip-off establishments would fatally drain my bard earned savings. Maybe the likes of Anne are not a good idea at this point in my life. Anyway, there is always Antoinette who can keep me company during the loneliest moments of my cursed existence. Haay! Talagang bubay na ito!

Charles saw from the bus window how the streets have grown bigger and brighter, signaling his approach into a district that mimics the layout, order, and cleanliness of a small first world city. He pondered: is it the intense business activity of this area that created such a dazzling cityscape, or is it the carefully planned urban space that magnetized and boosted both local and foreign enterprises? He tended to believe more on the second rather than on the first proposition, and justified his choice with the case of the congested and decaying appearance of the local Chinatown. Even with its decades of bustling commerce it cannot metamorphose into something like this part of Makati. I think it would take a mind of a visionary and the resources of a taipan to carve modern cityscapes out of the otherwise rambling metropolitan sprawl. From the bus stop, across a plush hotel with its landmark display of 
cascading water and lights, he walked again towards a high rise building where his office is located.

When he first came to that microcosm on Recto Street, Charles never thought that the good life that he had been enjoying would suddenly ground to a halt, much less that he would be forced to take a night job to sustain his studies. His father, Carlos Mendoza III, had a successful career as a trial lawyer in one of the biggest firms in Bulacan. When he deemed that he had saved and invested enough, at the age of fifty, he accepted a nomination, and eventual appointment, to a bench in their regional trial court. Charles took it for granted that he can go through college and law school, without worrying about tuition fees, allowances, and board and lodging expenses. Although the judge was stern with his discipline, he made it a point that his son would be comfortable with his studies, and visited him every time he had the chance to come to the metropolis.

If a lawyer's life is already stressful, a magistrate's existence is even more complicated, especially if one is as righteous and as compulsive worker as the Honorable Mendoza. He made it clear to his staff that after two years from his assumption of duty all the pending cases in his branch should have been given their appropriate decisions, while all the incoming cases should be treated with utmost efficiency and professionalism. Aside from the already crushing work schedule that he schematized, he had to keep an eagle's eye so that none of his crew would slip into the pit of bribery and extortion, as well as be exposed to the psychological and physical dangers of threats and assaults from the families and connections of some disgruntled litigants.

That kind of regimen could burn out even the toughest of all magistrates. So, at the age fifty-five, the admirable and extraordinary judge, Carlos Mendoza III, died of coronary ailment, and Charles was left to the care of his widowed grandmother. He could still recall how his grandmother talked to him during the wake of his father. "Charlie, bijo, halika dito. May sasabibin ako sa yo. Your father certainly had investments that can see you through college and even through law school. It had always been his dream that you add one more generation to our family's lineage of illustrious lawyers. Pero, hijo, I think you have to transfer to a less expensive school. Most preferably, you pursue your dreams here in our hometown. I know this will disappoint you. But we have to be practical and stretch out your inheritance. Ang importante ay magiging isang abogado ka, gaya ng pinangarap ng yumao mo'ng tatay."

"Lola, please. Let us talk about my fate after daddy's remains have been properly laid to rest. Let us explore together the other options available for me."

"Of course, of course, bijo. I am here not to dictate my wishes on you, but to help you fulfill your dreams and ambitions. Pasensya ka na. Labis lang siguro ang pag-aalala ko sa kapakanan mo."

However, Charles decided to stick it out with his elitist school and augmented his limited inheritance by taking a night job as a call center agent. Thus, after his father's remains were cremated, he was back in his school and in a few weeks' time he got a four hour a night and six nights a week job at the 
Concorde Communications International, the largest call center establishment in the country at that time. His grandmother had no choice but to support him with whatever she can: a little sum of money every now and then and lots and lots of prayer. The following semester, he had to slash off some subjects from the regular checklist to accommodate work, studies, writing, classroom hours and sleep in a day that is only twenty-four hours long, and his life went on.

Even the sidewalks of this financial district are wider and infinitely cleaner compared to their counterpart at Recto Street, or at any other place in the congested metropolis. They were paved with colored concrete, stamped with beveled designs, bordered with well-manicured greeneries, and illuminated by closely spaced halogen streetlamps. Striding through this path in the coolness of the late evening air was one of the simple pleasures that Charles anticipated each day. It gave him still moments to meditate on his life and conceptualize some visions for his future. But such an idyllic stroll would abruptly end at the lobby of the skyscraper that nestled the Concorde Communications International at its twentieth floor. Even at that late hour all the six elevators were still slithering up and down the building's spine, and the waiting area was crammed with agents who looked nothing like they were excited to report to work, but horde of zombies who were dragged out from their resting places to man that graveyard shift. Their stolid faces could not hide the fact that they were there not for the love of their work, nor for the desire to grow, and neither to express their loyalty to their company, but for the sole mission of earning money.

The company's main working area was a vast, garishly lighted, lowceilinged and super-cooled hall. At eye-level, it had no visible dividers, only the sparsely distanced columns, making all of its four walls visible from any point inside. Dozens of oversized clocks, telling the different times of some key cities around the globe, lined the perimeter. Knock down cubicles rose to four and a half feet from its white vinyl floor, and arranged in ten long rows, with each row carrying twenty-five computer monitors and phone sets. These could easily accommodate the company's peak time shift of two-hundred and twenty agents. What one can see from the main entrance were the blue-gray cubicle sidings topped with scores of bobbing ear-phoned heads, and some occasional agents rushing to and from a coffee, restroom, or meal break. The imposing phalanx of computer monitors and phone sets would not allow any leeway for an agent to personalize his or her work space, as he or she was not assigned to a specific permanent cubicle in the first place, but was merely instructed to take the nearest vacant spot upon arrival. This set-up ruled out the possibility of hanging a picture frame, or pinning a humorous cartoon or an inspirational quote, or of displaying fancy pen holders and mugs. In this very formal, impersonal, and antiseptic hall the agents must expect to land on a different bench every time they report to work or return from a short break. The overall appearance and cycle of work in this place strongly resembled the layout and system of a factory, justifying its and all other call centers' unsavory reputation as white-collar sweatshops. 
Many young people associated a call center agent's job with easy money, glamour, bar hopping, lots and lots of fun. There was even an urban legend that claimed that these agents are so westernized that many of them would readily indulge in casual sex inside their companies' dimly lit break rooms, as attested by their buildings' intermittently condom-clogged sewer pipes. There might be speckles of truth in all of these contemporary mythologies, but Charles looked at his job as inseparably woven with the torture it inflicts on the agent's mind and body. If Daddy were still around, be certainly would not allow me to toil in this dreary lot. The most difficult thing about this work is probably its initial violence of pulling us, agents, out of our own time zone, away from our normal vital rhythms, forcing us to be awake while the rest of the people are asleep, and making us asleep when the rest of the people are awake. Like an OFW who had to journey to a different place, and endure the pain and loneliness of his or her geographic dislocation, the agent had to journey to different time zones, and deal with the bizarre nature of his or her temporal dislocation. Charles was luckier, though, for his part-time status ensured that he had to suffer only half of what the full time agents had to suffer. After traveling through different time zones, when his work was done he could always come home to his own temporal niche and reintegrate himself into its vital rhythms. But that meant losing precious hours for his studies and writing.

Then, there is the drudgery of going through the endless train of phone calls, entertaining inquiries and complaints about alien products from strange sounding companies, and listening to disembodied voices strung with different emotions and in a variety of accents. This can easily numb our intellect and make our head hum with discordant sounds. Even in our own beds when we sleep, we can still hear reverberations of these electronic voices. This magnificent boredom can intensify during peak hours and seasons when the phone sets ring nonstop, when the inquiries and complaints become more repetitive, and when the voices grow more emotional and vitriolic. So as to squeeze the last cents of labor value from the agents, the eagle-eyed supervisors implemented the Concorde Communications International's tracking system that assured that each agent is glued to his or her phone set to receive the precious calls that generate the establishment's fabulous wealth, and that agent's coffee break would not exceed fifteen minutes, and his or her rest room break would not total beyond fifteen minutes for those working full time, and five minutes for those working part time. Knowing that he was closely and constantly monitored gave Charles creepy sensations.

Most of the reasons why people from the other side of the globe connect to their phone sets had something to do with a certain problem about a certain product that they purchased from any of their establishment's client companies. Thus, it was but expected that most of these callers were in brewing states of annoyance, of feeling aggrieved, of impatience, and of irritation, and that all it takes was one unclear answer, or one little mistake, to trigger in them a spree of cursing, verbal abuse, harangues, and racial slurs. "You moron!" "What the hell is wrong with this product, idiot?" "Stop reading your scripted answer, stupid!" "Listen to me, the problem is this gadget isn't working. So don't you ask me what's the problem!" "You are a Filipino, right? 
Fuck off flippin' monkey! Go back to the jungle!" Although the agents were all briefed to emotionally distance themselves from these expected outbursts, spending a huge portion of their working time dealing with such psychological harassment would certainly not add up into a pleasant and professionally fulfilling day. The overall stress when garnished with these tirades made half of the agents give up after just a short period of engagement. When I look around me there are always new faces, and my new acquaintances are gone before I even get the chance to know them better. For me, and the others who are left behind, company loyalty has no place in our hearts for our humanity is already deadened by the encompassing feeling of being transient. Talagang trabaho lang, at talagang walang personalan. Ang birap maghanapbubay dito.

Despite all the intended and unintended procedures of mental and bodily torture that the job inflicts on its agents, packs of young Filipinos continued to vie for its alleged persistently limited vacancies, Charles and thousands others carried on, and the country reaped financial gains in terms of taxes and the agents' local spending of their hard earned wages. In his more than a year of slaving in that company, he had not seen a single agent yet who seriously considered his or her current engagement as a lifetime career. All of them took their unhappy plight as a temporary arrangement until some financially and professionally better opportunities drift by. "Pansamantala lang to, tol." "Hinahantay ko lang 'yong application sa banko'ng 'yon." "Papunta na kasi kami'ng lahat sa States." "Para tayo'ng mga gago, nag-aral pa tayo ng kolehiyo. Eh, kahit elementarya lang ang natapos kaya'ng gawin 'to."

But the thought of how the government was gloating over the influx of more call centers and the expansions of the old ones, as if they were feats attributable to its strategic planning, left a taste of bile in his mouth. Putang ina! Every agent is aware that this kind offshore labor outsourcing thrives and grows on the coincidences that the operational and labor costs are lower on this part of the globe, that the young Filipinos could speak tolerable English, thanks to their long exposure to American films and cable channels, and that this youth seems to have an innate savvy for computers and other electronic gizmos, thanks to their growing up practically in video game arcades and internet cafés. Charles saw nothing very wrong with attracting more and more call centers in the country, but doing so while conveniently overlooking the development of agriculture and the manufacturing industries was totally another story.

After staying on his seat for two hours of uninterrupted phone conversations, Charles had just earned his right for a fifteen-minute coffee break. Agents would do a wide variety of things during this much awaited time. Some would use it literally for coffee at their kitchenette, others would slip outside of the building to replenish the fast depleting level of nicotine in their bloodstreams, still others would attempt to wrestle away their drowsiness by brisk walking around, but a few would just hang around the lobby and squander their precious time cursing their callers. "Putang ina itong mga puti na to!" "Mga gagong kano, ang bobobo!" "Tarantadong customer, reklamo ng reklamo bakit 'di daw gumagana ang desktop n'ya, samantalang brownout naman pala sa area nila!" Charles strategically utilized his fifteen minutes for a quick snooze at 
their break room. He seemed to have this rare gift of being able to fall into deep slumber in less than five minutes and remain there for another five minutes or so, before standing up refreshed and ready to hack through the remaining two hours of work. When he returned to the phone set, the business had grown brisker, and the electronic voices he heard expressed more emphatic emotions, in more assorted accents. Even the cursing, verbal abuses, harangues and racial slurs were streaming out with more vehemence. At four in the morning, his half time job for the day was done.

On ordinary days, Charles would go straight back to his dormitory and just take a real Filipino breakfast of tapsilog, cured beef, fried rice and eggs, in one of the food stalls there. But that day was a little different, aside from the fact that it was their weekly payday that coincided perfectly with his day-off from work; he was feeling too stressed with the endless succession of calls and displeased for not having a chance to browse through the philosophy books he carried with him to work. So, he decided to take a long leisurely breakfast at an American coffee chain just a block away from their office's building. Such a binge would surely make Sir Peter react violently, or Fred and Juliana frown. If my friends, my beloved uptight friends, were here, naku po, they would certainly insist on a less colonially colored tea house, or offer the less expensive El Viejo Mundo Café as a compromise. Of course, it is not that I do not like their choices; they are not just the places where I can easily drop by from work. So here I am to laze around in a sanctuary reserved for the rich and the social climbers. Bahala na, Charlie! Paminsan-minsan lang naman ito."

At the counter, Charles asked the cashier for a tall mug of hot chocolate and a piece of ensaymada that is baked with bits and pieces of ham and cheddar and sprinkled with grated parmesan. The register blinked his bill that surpassed half of the daily minimum wage, prompting Charles to rationalize his extravagance. Well, Charlie, here, is not just paying for the beverage and food but for the serene ambiance. Here, he can linger for some more moments even after his cup and plates are already cleaned. Relax, man. Enjoy the expensive surroundings.

While waiting for his order, he settled in a cozy corner where the lighting was suitable for reading and where there was a vacant cushioned armchair and a small coffee table. Charles started to browse through the pages of a book about the German philosopher and literary writer Friedrich Nietzsche, the man with a famous walrus mustache who formulated the famous slogan "God is dead." His fondness for this sage, who lived through the last decade of his life as an insane person, was what differentiates Charles' line of thinking from that of Sir Peter. Whereas Prof. Peter Mirano leaned towards the tradition of Marxism, the philosophy student Charles Mendoza was happily mixing the critical thoughts of Marx and Nietzsche. Charles' engagement with Nietzsche's thoughts was disrupted by the server who deftly laid down his hot drink and Spanish pastry on the coffee table. Even at those early hours of the dawn, the place was stirring with the convergence of those who were wrapping up their day and those who were about to start another day.

From where he was seated, Charles could not help but overhear the conversations of the other patrons. At a table near the window were three 
fifty-something males in jogger's outfits, they looked like powerful executives of some gargantuan corporations, and they were comparing the features of their favorite casinos in the bay area. The one with thinning gray hair was extolling the wonders of his choice, its variety of games, its luxurious ambiance, and its being free from lower class crowds. "Ay mga compadre ko, we should play there together one of these days!" At the sofa beside Charles' seat was a young couple, maybe on their way home from a party or some barhopping, who were debating about which film were they going to watch that evening. The lady was pressing for a Tagalog romance, while the male was insisting on a high-budget Hollywood thriller. "Alam mo naman na ayaw ko ng Tagalog films, napakabakya ng mga 'yon! If you want, we just watch our choices separately?" Around a low square table near them were four students, probably taking up law based on the hard bound and dark appearance of the books strewn in their midst, who were engrossed in establishing which gizmo was currently the coolest thing to have. Near the counter were two elderly women who, judging from their bland dresses, fans, shawls and prayer books, were on their way to an early mass. They were gossiping about a common friend who apparently could not join their daily spiritual regimen anymore. The one that reeked with a perfume that had been stored in closet a decade beyond its expiration was explaining to her companion: "Hay naku! That miserable lady, ever since their family business folded, she seemed to be unable to stay away from booze. Kawawa talaga!" The place was simply buzzing with mundane and fleeting talks. The drone made it difficult for Charles to follow the tortuously difficult thoughts of the book in front of him.

Dr. Silva had mentioned in their class earlier that semester how the German philosopher Jürgen Habermas had regarded the European coffee shops as the seedbed of public opinion. "History would tell us, my dear students, that during the seventeenth and eighteenth centuries, cafés sprouted in Europe. At alam n'yo ba ang implication nila? Aside from providing coffee, of course, these also gave the artists, writers, philosophers and other intellectuals a place to unwind and talk about literature, the arts and other ideas. Sooner these aesthetic conversations started to tackle problems about governance, economics and legislation. Kung baga sa atin, kapag ang mga kalalakihan ay magtitipontipon sa isang barberohan, kunyari, bindi maïwasan na ang usap-usapan nila ay pupunta at pupunta sa pulitika. Those gatherings and talks are what Habermas called a public sphere, a symbolic space where the state and the civil society can iron out public opinion and consensual ideas on how to improve and develop the state's governance and legislation."

But the idle chatting that threatened to engulf Charles inside that American coffee chain did not give him any promise that a public opinion could ever germinate from that place. On the contrary, he was certain that as the day would progress on the prattle would only grow louder and more frenzied, but would definitely not shift towards the reflection on nobler and relevant things. Uh oh, Sir Peter, Fred and Juliana are right, this is a bourgeois establishment and no one should expect dramatic ideas from places like this. Adios! Charles gobbled his pastry and swigged down his remaining chocolate, and stormed out 
of the shop towards the light rail station, where a train will take him back to their microcosm on Recto Street.

At daybreak, in their dormitory room, Fred was already poring over some chapters and notes on advanced industrial chemistry, apparently in preparation for a major examination. The room that the two buddies shared was just nine square meters small, low-ceilinged, unpainted, musty, and devoid of any plumbing, as the six shower and toilet cubicles were all downstairs for all of the eighteen occupants of their men's dormitory. It was obvious that Charles and Fred landed on that decaying and crowded place for the sole reason of its affordability. Without disturbing his friend, Charles silently gathered his toiletries and proceeded to take a quick shower. When he returned, he softly bade Fred good luck for his test, reminded him of their scheduled business late that afternoon, switched on second-hand desk fan in anticipation of the temperature that would rise with the sun, and crawled on his single size bed.

After a few minutes, Fred left the room for his early morning classes. "Goodbye, Charlie! Have a restful sleep. I won't forget our appointment. See you later, man!"

"Thanks Freddie! You are such a great friend. Don't forget to say bi to Ms. Faith for me." Charles tried to lull himself to sleep by gazing at the mess on his study table. The photocopied portrait of Nietzsche pinned on the wall seemed to be looking intently at a dark Ifugao rice god squatting over a sheaf of notes as if guarding the arcane knowledge contained in an open philosophy book. A miniature bust of Socrates, which Juliana bought for him as a birthday present from a curio store in Makati, served as a bookend stand for his equally cluttered shelf. Near the center of the table was a small framed photograph of Charles' small family.

They all looked happy in that picture. His father, at the prime of his health, wrapped his beefy arms around the lithe figure of his lovely mother, and the scrawny Charles with a Cheshire grin stood in front of them. It was taken when he was in grade six, when they were about to leave their house for a Sunday mass. Charles can vividly recall how those weekly visits to the Malolos church were usually followed with a lunch at the most expensive restaurants down town, and then with shopping for clothes, electronic gadgets and books. He really missed those days.

But less than two years after that photograph was taken, his parents separated. He did not see it coming, and he was left devastated. By hindsight he realized that it was the nature of his father's job, its seemingly endless hours of paper works, almost nightly meetings with clients, and more take home tasks that put so much strain on their marriage. As his mother had devoted all her time for the household and never had the opportunity of having a job, Charles was momentarily placed under the custody of his father. But the Mendoza family of lawyers hatched up a scheme to make the arrangement permanent by hiding Charles away from his mother. When she took a job as a domestic helper in Milan, Italy, the Mendozas foiled all her attempts to establish contact with her growing son. Charles learned late in high school how his father and 
his grandmother had connived to burn all incoming letters with Italian stamps. $\mathrm{He}$ comprehended that they were all simply victims of cruel circumstances. $\mathrm{He}$ continued to love his mother just as he loved the memory of his father. Someday, soon, I will find you, mommy; even if that would mean rummaging through the whole of Milan for you. Finally, the bone-weary call center agent and philosophy student drifted into a peaceful sleep. A faint smile brightened his face, probably he was dreaming he was ten years old again playing in their small house in Malolos, Bulacan, where everything was simple, whole and complete.

That afternoon, Charles was enthusiastically following the lecture of Prof. Mar Varoza in their Filipino philosophy class. His professor was in effect making an autopsy of the demise of a postcolonial movement in Philippine social sciences that was initiated by the late Dr. Virgilio Enriquez, one of the distinguished founders of Sikolohiyang Pilipino.

"Class, as you know already, Dr. Enriquez advocated the idea that the Filipino must be understood using Filipino concepts and theories. Hence, the local social sciences should get rid of its western categories and instead explore, utilize and develop the existing notions and frameworks that the local folks use in making sense of themselves and their society. However, in less than a decade after this genius died, his revolutionary project lost momentum and grounded to a halt, as his initial followers slipped back to their untrammeled use of western thoughts." Prof. Varoza explained that no matter how noble and nationalistic Dr. Enriquez' advocacy had been, it was predestined to perish for the reason that it pitted itself against the well ingrained, widely accepted, and well funded western-style social sciences. "The more powerful western discourse simply lashed back with fatal blows at the still budding indigenous discourse." Prof. Varoza clarified, however, that this tragic fate did not imply that Dr. Enriquez' postcolonial project had rested eternally, for it was not impossible that someday other intellectuals would tackle again his cause, and no one can predict what outcomes they may have.

From where he was seated, Charles could smell the thoughts of Marx and Nietzsche in Prof. Varoza's forensic analysis as distinctly as he could smell the sweet floral scent of Anne's perfume. Her seat was just in front of him, and as she was busily scribbling her notes, Charles noticed how gracefully her delicate hand held her sign pen. Charles started to fantasize a scenario where he could have a perfect opportunity to invite her to El Viejo Mundo Café. But if ever she would indeed grace such offer, he wondered what stuff they should talk about while having coffee. From his several semesters of surveillance he knew already that she was a fan of the existential thinkers, like Jean-Paul Sartre and Martin Buber. These philosophers might be excellent subject matters for a minor class in philosophy of the person, for they talk about freedom, the actualization of one's potentialities, and the humane way of dealing with other persons; but, hayy Dios mio naman, I am convinced that they are too self-centered and bourgeois, for they have the tendency to gloss over the social and political problems even if these are practically jutting in front of their faces. Instead they harden and condition the self to just stoically endure such circumscribing problems and to refrain from aspiring to dismantle them. Charles believed that Filipino philosophy students have to go beyond existentialism, and he 
shuddered at the thought of having to suffer through an hour of existential discussion, even with the ethereally lovely Anne, even in the romantic ambiance of the El Viejo Mundo Café.

He failed to notice that Prof. Varoza had already left the room and it was the turn of Prof. Ramon Rafael to expose the spirituality behind the overrated Kama Sutra for their oriental philosophy class. About five years back, this professor had been summoned to appear before the academic council after the head of the instructional materials department squealed that he presented to his junior class a Penthouse documentary on this Indian erotica. A curt explanation on the significance and sacredness of the Kama Sutra intertwined with a citation of the doctrine of academic freedom eventually cleared his name. Nevertheless, he toned down his visual aids by replacing the Penthouse video production with a slide projection of some ancient Indian illustrations, which although more visually explicit were not the kind of stuff that would usually catch the attention of nosy administrators. At six in the evening, after Prof. Rafael abruptly wrapped up his comparison between the western tendency to chain human sexuality and the Indian technique of totally unleashing it, Charles nimbly negotiated in less than ten minutes the height and distance from his classroom to that mall located at the midsection of Recto Street. Sobra yatang excited ako ngayon. Kaya tuloy, para akong si Flash Gordon, at one moment nasa classroom pa, the following moment tadaaang, ayun 'andito na.

He was distressed to see how the high- and middle-end shops of that five-storey business establishment had folded up to give way to the thriving number of cellular phone stalls, gaming arcades, video-karaoke galleries, and bargain outlets, projecting an overall impression that one was in the belly of a mammoth flea market. Charles could identify a handful of hookers of both sexes bustling around trying to attract prospective clients among the straight and homosexual male shoppers. "Bossing, ano'ng 'banap n'yo? Babae? Lalaki? Beke? Bata? Medyo may edad na? Colegiala? Sabibin n'yo lang, t'yak may makukuba tayo. Affordable dito ang rates." An old toothless pimp was beginning to irritate him. Luckily, Fred arrived from his research work at the university and Charles led him to a back exit that connected them into a maze of narrow alleys. "Halika dito, Freddie. Just follow me. Ingat ka lang, medyo maputik ang daan." At the end of what seemed to be a dark tunnel was a neon billboard that announced the name of a seedy strip joint, Miss Asia-Pacific Music Lounge. Charles had been planning to introduce his buddy, Fred, to his lady friend, Antoinette, whose existence and identity he kept secret from him a little too long. It was only that previous day that he mustered enough courage to make that scheme a reality that night.

Before entering the club, a broad-shouldered Ilocano in an ill-fitting black vest gave them some thorough frisking for concealed weapons. "Saglit lang mga bossing, no search no entry ang policy $n g$ management kasi. Pasensya na sa abala." Charles whispered to Fred: "Hmmph, maniwala ka dyan. That standard operating procedure is intended more on foiling any attempts to smuggle in peanuts, chips, and other beer mates than on actually confiscating guns or sharp objects." The guard, who was also the porter, the information clerk, and 
the bouncer, all the same time, tapped some coded knocks on the hermetically sealed red door prompting it to open into a humid and smoky hall that stank of rodent and roach droppings. Fred struggled to adjust himself to an ambiance that was made disorienting by the earsplitting music, the incomprehensible American-inspired babbling of the disc jockey, the bawdy crowd, and the sporadic flashes of strobe light. On the ledge was a rather beautiful young lady gyrating to the tune of a 1990s hit. She was wearing an exaggeratedly abridged version of the white and pink uniform worn by the university students across Charles' college. As she started to peel off her academic costume, the waiter blocked their view guiding them with a penlight to a vacant spot just a few feet away from the ledge. "Dito po tayo, mga bossing. The center stage is very visible from here. I will get your additional orders in a while."

Their rickety table was layered with a flimsy plastic material, bearing a printed design of fiesta buffet table. Through the maps and circles of soy sauce stain and pock marks of cigarette burns, Fred could discern the images of a roasted pig, and a heaping tray of local fruits. The waiter dexterously set four bottles of beer, an ashtray, and a battered aluminum ice bucket with a spoon in it instead of a tong, and gasping through his tight first communicant's bowtie, he asked if they would like to order something to go with their drinks. "Chicharong bulaklak? Sisig? Calamares? May kambing din tayo dito kung gusto n'yo." Without looking at the menu, Charles snapped: "Just a bowl of mix nuts, pare, the ones fried with lots of red chili and garlic. Salamat!" The blaring music faded, the lights dimmed, the performer walked down from the ledge, and the disc jockey mumbled some more incomprehensible tidings. "Laydiz and gentlemin, that was gorgeous performer, pride of Malabon City, Miss Epple! In a little while, Laydiz and gentlemin, equally gorgeous solo artist will entertain us with her latest dance number. So sit back and relax, enjoy the fun only here in Miss Asia-Pacific Music Lounge!" Charles apologetically explained to Fred: "I'm sure you are a little bit uneasy with the place and the characters around. But just disregard them. Hang on for some moments, Freddie. I want you to focus all your attention on her when she finally comes out."

Indeed, when the music and lights returned a breath-taking apparition materialized through the cloud of artificial smoke. Charles cleared his throat and hesitantly whispered to Fred. "Look closely. That girl on the ledge, the one wearing a Japanese high school uniform of white and navy blue and black knee socks, is Antoinette. Ang ganda n'ya, ano?" Fred could not disagree with his friend's aesthetic judgment, but he doubted whether the name was real or not. Filipino entertainers and sex workers are too fond of using made up American sounding names: from Allyson to Blanche to Courtney and even Xyrene, or Yvonne, or Zoe. But whatever her true name was, no one could really refute the clearest fact that she possessed a face and physique that would make even the prettiest students at the university belt pale in comparison. When she danced with the purest grace, it was breathtaking; and when she ripped off her costume to reveal a smooth and voluptuous body covered only by leopard skin lingerie the world seemed to stand still. She was Antoinette, star performer of the Miss Asia-Pacific Music Lounge. 
When her dance number ended she went to the dressing room just to put on a more substantial outfit and immediately proceeded to where Charles and Fred were seated. "Good evening, Charlie, and I assume, Fred? Kayo ba si Fred?" The two students were overwhelmed by the feminine whiff of her freshly shampooed and conditioned hair and vanilla scented skin lotion. "Yes. Yes. I am Freddie, kaibigan ni Charles." The waiter, seeing her settle at their table, promptly took her choice of drinks, which Charles had to pay for a whooping equivalent value of the daily minimum wage. Only a fifth of that amount would go to her as commission for entertaining the guests, while the rest would belong to the management. Fred could determine her distinctive accent as Visayan, the language which in the metropolis is stigmatized as the idiolect of the less privileged denizens such as the local domestic helpers, construction workers, massage attendants, drivers, GROs, seafarers, prize fighters, and other sweatshop toilers.

After draining her first tall glass of the country's second class brew, Antoinette began to be a little loquacious and recounted how she came to the metropolis from Northern Mindanao, like a moth drawn to the promises of a flickering candle flame. "Hayy naku, Freddie! Malungkot ang naging kwento ng bubay ko. An agent brought me here to work as a clerk in a dry goods store. I was paid like a house maid and was whisked to and from the shop together with the other ladies. It was a boring and back-breaking job and my earnings were not enough to support my parents in the province. But my rapid descent into this miserable pit did not start until I made the big mistake of having an affair with the married store manager. Walang-hiya'ng gago'ng 'yon! He left me with my poor, frail and sickly daughter. She is now in Mindanao, with my parents. Nakakamiss, pero s'ya ang inspirasyon ko na magtrabaho ng maigi." Although, explicitly she was a performer and GRO, everyone knows that line that separates these professions from prostitution is so thin, hazy and almost non-existent.

In the course of their conversation, Fred realized that Charles and Antoinette had known each other for quite a long time, had already a number of dates at the plush Makati malls, and even had dinners at her Pasay apartment. What Fred could not figure out was his friend's point of bringing him there and introducing him to that wretched beauty. I wonder if Charles here is really serious with this lady, if he is strong enough to face other people's reaction upon knowing that he is in love with a stripper, and how long this affair would last before he staggers down from the pain of seeing her work with moneyed older men or of hearing stories about her past. We may have spent so many hours talking about the need for the intellectuals to empathize with the lower classes, and about the artificiality of the socially constructed identities, but I think I am just not prepared to see my friend going as far as actually implementing such armchair ideals within his own precious life.

After her third glass of grossly overpriced beer, she whispered an apology to Charles's ears. "I am so sorry, Charlie. I have to go back to our waiting booth. One of my big time guests will soon arrive and he is expecting my company. Balik kayo dito palagi ha, Fred? Ipapakilala kita kay Apple, next time!" Charles' cheerful disposition darkened no matter how he rationalized to 
himself that she had to attend to the other guests in order to earn not only for her daughter, or for her aging parents in the province, but most of all for her own self. The retirement age for the profession of stripping was quite early, and Antoinette had to save as much as she can before the swift years etch their tell tale lines on her face and make areas of her gorgeous body sag.

With her gone, the two students struggled to focus their attention again on the ledge, on a black latex-attired performer swaying like a creaking automaton. They had clearly lost the party mood they had just brought with them to that music lounge and the remaining beer and nuts on their table suddenly seemed tasteless.

Then, a short but heavy built man in his late fifties, wearing an intricately embroidered barong Tagalog, accompanied by three less distinguished looking associates, probably his body guards, walked through the entrance. Two floor managers and a waiter fussed over them and led them to the best table available. "Ay, Sir, good evening po! Dito po kayo sa favorite place n'yo. Lalabas na po s'ya mayamaya."

"Sige, hijo, bigyan mo kami ng Carlos Primero at 'yong kambing na specialty n'yo. At p'wede bang binaan n'yo ng kaunti 'yang tugtog n'yo?" Within a few minutes Antoinette, appearing uneasy, joined the newly arrived group. The balding guest unceremoniously grabbed her slender and beautiful body, made her sit on his lap, wrapped his sinewy arms around her, and started kissing and fondling her. She anxiously and helplessly looked at the direction of Charles and Fred. Charles pretended to be absorbed by the hideous dance number on the ledge.

As Fred was certain that his friend was not prepared to personally witness such a painful scene, he instinctively settled their bill and convinced his friend that it was already time for them to go back to their dormitory room. "Tayo na Charlie, marami pa tayo'ng dapat gagawin." Their walk back to that place near Recto Street that they both called home seemed like a funeral march in somberness and silence. They dropped by a food stall in front of their dormitory. "Charlie, we should take something more substantial than those fried peanuts."

"I am not that hungry, Freddie. Let us just have coffee." So they bought two Styrofoam cups of instant coffee. In their room Fred waited until Charles settled on his bed before telling him that he had to bring Juliana some warm chocolate and sandwich at the hospital where she was having her training. "You need some rest now, pare. I promise you, we should go back to that music lounge some other time." there."

"You don't have to do that, Freddie. I'm so sorry for taking you

"I'm okay, man. It was an experience, I may say. Oh, Juliana will be waiting for me in a few minutes."

Alone in their asphyxiating dormitory room, Charles stared emptily at the patterns left by the flaking paint on the ceiling. Slowly he rose from his bed and fumbled through his drawer until he found a stashed sachet of crystalline powder, a piece of tin foil, and a small alcohol lamp. Sometimes when one was driven towards the dead end alley of his cursed existence, that 
enchanted powder provided the only way out. As the forbidden incense clouded his troubled mind, the too familiar dream faded in again.

The grayish yellow cobble stones materialized under his feet, the breeze became cooler, and he could hear the gurgling sound of an old fountain at the middle of an Italian town square. He was sitting on a bench of intricately wrought iron and wood looking at his girl, a cross between Anne and Antoinette, who was childishly casting a paper bagful of seeds to a flock of pigeons. "Carlito, Carlito, amore mio! Look at the birds! Bellisimo! Very beautiful, no!" He was a little surprised to see the composite image, the Anne-toinette, speaking in the Italian language. But he immediately shrugged it off, for in that exuberant dream-world who really would care.

The lovely lady took his hand and led him through the narrow Medieval streets. In front of a jewelry shop they asked an old lady with a dark shawl: "Buon giorno, señora! Per favore, do you happen to know where Beatriz Mendoza is working? She is a Filipina domestic helper." She shook her head and made an elaborate gesture with her hands: "Non lo so. I do not know." Near a bakeshop they asked a young man with a loaf of bread tucked under his arms: "Buon giorno, señore! Per favore. Parla inglesse? Do you speak English?" He too shook his head and gestured with both hands: "Non capisco. Scusil" So did the burly tavern keeper with a greasy apron, and the young chap with a wheelbarrow full of vegetables. But the solitary writer with a too familiar walrus moustache sitting in an open air café, spoke to him in a different language: "Karl, Sie warden geisteskrank, gerade wie ich. You are getting insane, just like me. Erwecken Sie durch jungen Mann! Wake up young man!" Charles was bewildered why no one seemed to know the whereabouts of his mother. $\mathrm{He}$ and the composite of Anne and Antoinette walked on and on until the village disappeared behind them. His legs ached and the intensely stunning Italian afternoon dissolved into the blackest of nights. The olive trees at the roadside began to sway low and strangle them with their sharp branches. As the Annetoinette screamed she slowly transmogrified into a hideous wraith with a face of his supervisor at the Concorde Communications International.

Engulfed in darkness Charles, Carlito, or Karl, held on to the old framed photograph that was taken when he was still twelve years old in their small house in Malolos, Bulacan, where everything was simple, whole and complete. 